\title{
Penerapan Media Pembelajaran Flipbook Interaktif untuk Meningkatkan Hasil Belajar Siswa
}

\author{
Diana Rahayu ${ }^{1 *}$, R Ading Pramadi ${ }^{1}$, Meti Maspupah ${ }^{1}$, Tri Wahyuni Agustina ${ }^{1}$ \\ ${ }^{1}$ Prodi Pendidikan Biologi, FTK, UIN Sunan Gunung Djati, Bandung \\ "E-mail: dianarahayu513@gmail.com
}

\begin{abstract}
Abstrak
Tujuan penelitian ini adalah untuk mendeskripsikan keterlaksanaan proses pembelajaran, menganalisis hasil belajar siswa, dan mendeskripsikan respon siswa terhadap penggunaan media pembelajaran Flipbook Interaktif. Metode yang digunakan adalah Pre-Experimental dengan pretest-posttest desain dengan jumlah sampel sebanyak 30 siswa yang diambil dengan menggunakan teknik purposive sample. Instrumen yang digunakan dalam penelitian ini yaitu menggunakan lembar observasi, soal pilihan ganda, dan angket respon siswa. Berdasarkan hasil analisis data keterlaksanaan pembelajaran dapat terlaksana dengan baik, dengan rata-rata keterlaksanaan aktivitas guru sebesar $94 \%$ dan rata-rata keterlaksanaan aktivitas siswa sebesar 74,16\%. Penggunaan media pembelajaran Flipbook Interaktif pada materi Struktur dan Fungsi Sel dapat membantu secara signifikan meningkatkan hasil belajar siswa sebesar N-Gain 0,43\% dengan kategori sedang. Respon siswa terhadap pembelajaran dengan menggunaakn media pembelajaran Flipbook Interaktif pada materi Struktur dan Fungsi Sel adalah 81\% dengan kategori sangat tinggi.
\end{abstract}

Kata kunci: Flipbook Interaktif, Hasil Belajar, Media Pembelajaran, Struktur dan Fungsi Sel

\section{PENDAHULUAN}

Pendidikan berperan penting dalam meningkatkan sumber daya manusia yang mampu bersaing dengan dunia. Abad 21 merupakan era globalisasi dengan kemajuan ilmu pengetahuan dan teknologi yang pesat sehingga mepermudahkan pekerjaan manusia dan menimbulkan persaingan dan tatangan yang lebih kuat. Setiap negara berlomba-lomba dalam meningkatkan sumber daya manusia, salah satunya melalui pendidikan. Sumber daya manusia dengan nilai yang tinggi yaitu indivudu yang memiliki kehidupan berkualitas melalui pengetahuan dan kemampuan yang dimilikinya. Pendidikan formal yang dilakukan di sekolah dapat menciptakan pembelajaran yang menyenangkan sehingga memotivasi manusia untuk belajar (Sholihah, 2019: 35).

Pada akhir tahun 2019, dunia digemparkan dengan pandemi Covid-19 yang disebabkan oleh virus SARS Cov2 yang mudah menyebar secara cepat melalui droplet orang yang terinfeksi. Pandemi ini berdampak diseluruh negara tak terkecuali indonesia. Setiap negara melakukan upaya pemutusan pandemi ini dengan mengadakan lockdown yaitu semua kegiatan dilakukan dari rumah. Dampak ini dirasakan oleh berbagai 
bidang dan salah satunya adalah dunia pendidikan (Putria, 2020: 863).

Dengan adanya pandemi covid-19 seluruh pendidikan dipakasa untuk beradaptasi dengan keadaan baru yaitu dengan melakukan kegiatan belajar mengajar dari rumah guna memutus rantai penyebaran Covid-19. Pembelajaran dari rumah atau yang sering dikenal dengan belajar daring (dalam jaringan) mebuat peserta didik dan tenaga pendidik merasa terkejut karena hal ini terjadi secara tibatiba tanpa adanya persiapan yang matang, sehingga menimbulkan berbagai masalah bagi pendidikan. Keadaan ini merupakan tantangan yang besar karena disini pendidik dituntut untuk kereatif dan berinovatif dalam menyampaikan materi dan didikan kepada peserta didik (Istani, 2020: 23).

Pembelajaran daring menimbulkan dampak yang kurang baik bagi proses pembelajaran siswa, dimana saat proses pembelajaran daring siswa mulai merasa jenuh dan bosan dalam belajar karena kegiatan belajar yang dirasa monoton tanpa adanya interaksi secara nyata membuat motivasi belajar siswa semakin menurun sehingga hasil belajar siswa pun menurun (Putria, 2020: 869).

Berdasarkan wawancara dengan guru Biologi SMA Negeri 1 Pedes, semasa pembelajaran daring menimbulkan masalah pada hasil belajar siswa hal ini dilihat dari menurunnya jumlah siswa yang tuntas KKM (Kriteria Ketuntasan Minimal), terlambat mengirimkan tugas dan kurang aktif dalam proses pembelajaran. Berdasarkan wawancara dengan siswa menurunnya hasil belajar sisiwa disebabkan oleh berbagai faktor seperti siswa mulai jenuh dengan pembelajaran daring, tidak paham terhadap materi, masalah kuota, jaringan, alat belajar seperti handphone dan waktu belajar siswa yang terganggu karena harus membantu orang tua di rumah.

Menurut Kurniawan (2017: 157), hasil belajar merupakan hal yang penting dalam kegiatan pembelajaran, karena keberhasilan dan ketercapaian tujuan pembelajaran dilihat dari hasil belajar siswa. Hasil belajar siswa yang tinggi dapat menunjukan bahwa siswa telah memahami materi pembelajaran yang diberikan, begitupun sebaliknya jika hasil belajar siswa rendah dapan menunjukan permasalahan mengenai pemahaman siswa terhadap materi pembelajaran. Hasil belajar dapat dilihat dari perubahan yang terlihat pada siswa baik perubahan kognitif, apektif, maupun psikomotorik.

Upaya yang dapat dilakakan oleh guru untuk meningkatkan hasil belajar siswa dengan memberikan pembelajaran daring yang dikemas dengan media yang menarik. Media pembelajaran daring yang digunakan di SMA Negeri 1 Pedes berupa e-modul yang dikirim melalui google classroom dan LKS pegangan siswa. Menurut Sri (2019), media pembelajaran merupakanalatbantuguruyangdigunakan untuk menyampaikan informasi berupa gambar, audio, objek, model, dan lainnya yang dapat meningkatkan motivasi dan memberikan pengalaman yang nyata kepada siswa sehingga tercapainya tujuan pembelajaran. Seiring perkembangan 
teknologi, informasi, dan komunikasi media pembelajran pun semakin berkembang mengikuti perubahan zaman yang awalnya berupa media konvensional hingga menjadi media modern yang berbantu teknologi.

Berdasarkan uraian diatas maka perlu adanya inovasi dalam penggunaan media pembelajaran yang dapat memotivasi dan memudahkan siswa dalam memahami materi pembelajaran, sehingga dapat meningkatkan hasil belajar siswa. Salah satu media pembelajaran berbasis teknologi yang dapat dikembangkan dan digunakan yaitu media flipbook interaktif. Menurut Mulyadi (2016: 298), menyatakan bahwa flipbook merupakan media menyerupai buku dengan setiap halamannya dilengkapi dengan animasi atau proses yang bergerak. Flipbook dapat dilengkapi dengan teks, animasi, gambar, video, dan suara, sehingga dapat terciptanya pembelajaran yang interaktif dan memotivasi siswa dalam belajar serta lebih mudah menstimulus daya ingat siswa sehingga dapat meningkatkan hasil belajar siswa.

Flipbook yang dilengkapi dengan animasi, gambar, video, dan suara dapat menjadikannya sebagai media pembelajaran yang menarik bagi siswa. Media pembelajaran yang menarik akan menjadi rangsangan bagi siswa dalam proses pembelajaran (Nurrita, 2018), yang pada akhirnya akan meningkatkan minat dan hasil belajar siswa.

Materi yang akan digunakan pada penelitian ini yaitu materi struktur dan fungsi sel. Menurut Purnamasari (2019: 1), materi struktur dan fungsi sel merupakan materi yang diajarkan di jenjang SMA kelas XI. Berdasarkan hasil wawancara dengan guru dan siswa bahwa materi struktur dan fungsi sel merupakan materi yang kompleks dan rumit namun perlu diajarkan kepada siswa karena merupakan materi yang berkaitan dengan masalah di kehidupan sehari-hari. Materi struktur dan fungsi sel dirasakan sulit dipahami oleh siswa karena pada materi ini membahas tentang komponen kimiawi penyusun sel, struktur, fungsi, dan proses yang berlangsung dalam sel sebagai unit terkecil kehidupan, sehingga pada materi ini perlu adanya sebuah media yang dapat membantu proses pembelajaran siswa.

Berdasarkan uraian permasalahan diatas, perlu dilakukan penelitian dengan judul "Penerapan Media Pembelajaran Flipbook Interaktif Untuk Meningkatkan Hasil Belajar Siswa Pada Materi Struktur dan Fungsi Sel".

\section{METODE}

Metode yang digunkan dalam penelitian ini adalah metode PreExperimental Design dengan One-Group Pretest-Posttest Design. Metode ini hanya menggunakan satu kelompok yaitu sebagai kelompok ekperimen dengan pembelajaran menggunakan media flipbook interaktif. Sampel yang digunakan dalam penelitian ini diambil dengan teknik purposive sample yaitu sampel dipilih dan ditentukan oleh guru Biologi berdasarkan karakter siswa, kemampuan, dan jumlah siswa dalam satu kelas agar tujuan pembelajaran dapat tercapai. Kelas 
yang terpilih sebagai kelas eksperimen yaitu kelas XI MIPA 5 dengan jumlah sampel sebanyak 30 siswa. Instrumen pengumpulan data menggunakan lembar observasi, lembar soal, dan angket. Penelitian ini dilakukan di SMA Negeri 1 Pedes secara virtual/online yang dilaksanakan dimulai dari bulan Mei hingga bulan Agustus 2021 melalui tiga tahap yaitu tahap perencanaan, tahap pelaksanaan, dan tahap akhir.

\section{HASIL DAN PEMBAHASAN}

A. Keterlaksanaan Pembelajaran

1. Keterlaksanaan aktivitas guru

Keterlaksanaan aktivitas guru diperoleh dari hasil lembar observasi yang digunakan oleh observer untuk pengamatan. Keterlaksanaan aktivitas guru dalam proses pembelajarn terdapat pada Tabel 1.

Table 1. Keterlaksanaan Aktivitas Guru

\begin{tabular}{ccc}
\hline $\begin{array}{c}\text { Per- } \\
\text { temuan }\end{array}$ & $\begin{array}{c}\text { Keterlaksanaan } \\
(\mathbf{\%})\end{array}$ & Interpretasi \\
\hline Pertama & 88 & Sangat Baik \\
Kedua & 100 & Sangat Baik \\
\hline $\begin{array}{c}\text { Rata-rata } \\
(\% \pm \mathrm{sd})\end{array}$ & $94 \pm 8,5$ & Sangat Baik \\
\hline
\end{tabular}

Berdasarkan Tabel 1. diketahui bahwa keterlaksanaan aktivitas guru dalam pembelajaran menggunakan media pembelajaran Flipbook interaktif pada meteri struktur dan fungsi sel pada pertemuan pertama kurang maksimal dengan memperoleh rata-rata $88 \%$ dengan interpretasi sangat baik. Sedangkan aktivitas guru yang tidak terlaksana memperoleh rata-rata $13 \%$. Hal ini disebabkan karena pengaturan waktu yang kurang maksimal sehingga proeses pembelajaran kurang efektif. Menurut Fadilah (2019: 152), bahwa dalam kegiatan pembelajaaran guru harus mempersiapkan rencana pembelajaran secara matang, dengan adanya perencanaan pembelajaran ini maka kegiatan pembelajaran dapat berjalan sesuai tahapan pembelajaran, serta adanya antisipatif terhadap kesenjangan sehingga dapat tercapainya tujuan pembelajran. Pada pertemuan kedua terdapat peningkatan dari pertemuan pertama. Hal ini dibuktikan dari perolehan analisis data keterlaksanaan aktivitas guru dengan rata-rata persentase 100\% dengan interpretasi sangat baik. Keterlaksanaan aktivitas guru selama dua kali pertemuan memperoleh ratarata persentase sebesar $94 \%$ dengan interpretasi sangat baik. Sehingga dapat disimpulkan keterlaksanaan aktivitas guru ini berjalan dengan baik.

2. Keterlaksanaan aktivitas siswa

Keterlaksanaan aktivitas siswa dalam proses pembelajaran menggunakan media pembelajaran Flipbook interaktif diperoleh dari lembar observasi yang digunakan oleh observer dan guru untuk pengamatan. Keterlaksanaan aktivitas siswa dalam proses pembelajarn terdapat pada Tabel 2.

Table 2. Keterlaksanaan Aktivitas Siswa

\begin{tabular}{ccc}
\hline $\begin{array}{c}\text { Per- } \\
\text { temuan }\end{array}$ & $\begin{array}{c}\text { Keterlaksanaan } \\
\mathbf{( \% )}\end{array}$ & Interpretasi \\
\hline Pertama & 70 & Baik \\
Kedua & 78,3 & Baik \\
\hline
\end{tabular}




\begin{tabular}{ccc}
\hline $\begin{array}{c}\text { Per- } \\
\text { temuan }\end{array}$ & $\begin{array}{c}\text { Keterlaksanaan } \\
(\mathbf{\%})\end{array}$ & Interpretasi \\
\hline $\begin{array}{c}\text { Rata-rata } \\
(\% \pm \mathrm{sd})\end{array}$ & $74,16 \pm 5,9$ & Baik \\
\hline
\end{tabular}

Berdasarkan Tabel 2. diketahui bahwa keterlaksanaan aktivitas siswa dalam proses pembelajaran menggunakan media pembelajaran Flipbook Interaktif pada pertemuan pertama dan kedua mendapatkan ratarata persentase sebesar 74,16\% dengan interpretasi baik. Pada pertemuan pertama diperoleh hasil rata-rata persentase $70 \%$ dengan interpretasi baik, namun sebesar 30\% pembelajaran tidak terlaksana. Sedangkan pada pertemuan kedua terdapat peningkatan dari pertemuan pertama dengan hasil analisis rata-rata persentase sebesar $78,3 \%$ dengan interpretasi baik. Ketidak terlaksanaa aktivitas siswa ini disebabkan terdapat siswa yang kurang responsif di Google Classroom seperti hanya terdapat sebagian siswa yang merespon saat guru memberikan salam, membuka, dan menutup pembelajaran. Oleh karena itu pelu tertanamnya tanggungjawab serta motivasi siswa dalam belajar agar tercapainya tujuan pembelajaran. Hal ini sesuai dengan pendapat Halik (2020: 138), pembelajaran secara daring mengharuskan siswa untuk menumbuhkan kesadaran diri dan mengatur diri sendiri sesuai kemampuannya sehingga dapat munculnya motivasi belajar pada siswa. Selain itu juga guru berperan penting terhadap penumbuhan motivasi ini dengan cara memberikan penguatan, karena dengan penguatan ini akan menciptakan keaktifan siswa dalam belajar.

B. Peningkatan Hasil Belajar Siswa dengan Menggunakan Media Pembelajaran Flipbook Interaktif pada Materi Struktur dan Fungsi Sel

Peningkatan hasil belajar siswa dengan menggunakan media pembelajaran Flipbook Interaktif yang dilakukan di kelas XI MIPA 5 meliputi pencapaian KKM dan pencapaian nilai kognitif.

1. Ketercapaian kognitif

Ketercapaian nilai KKM yang diperoleh dari siswa kelas XI MIPA 5 sebagaimana yang terdapat pada Tabel 3.

Tabel 3. menunjukan bahwa ketercapaian keberhasilan belajar setiap siswa dapat ditentukan melalui besarnya nilai KKM. Nilai KKM ini menjadi acuan paling rendah bahwa siswa tersebut tuntas dalam belajar. KKM mata pelajaran Biologi yang berlaku di SMAN 1 Pedes sebesar 74. Persentase ketuntasan KKM yang diperoeleh pada kelas XI MIPA 5 yaitu sebesar 57\% dengan jumlah 17 dari 30 siswa yang dinyatakan tuntas. Sehingga dapat disimpulkan bahwa

Table 3. Ketercapaian KKM Siswa

\begin{tabular}{cccccc}
\hline Kelas & Nilai KKM & $\begin{array}{c}\text { Siswa < Nilai } \\
\text { KKM }\end{array}$ & Persentase & $\begin{array}{c}\text { Siswa > Nilai } \\
\text { KKM }\end{array}$ & Persentase \\
\hline XI MIPA 5 & 74 & 13 & $43 \%$ & 17 & $57 \%$ \\
\hline
\end{tabular}


proses belajar cukup baik, namun cukup banyak siswa yang belum tuntas KKM, hal ini dapat disebabkan dari beberapa faktor seperti motivasi belajar, minat, kebiasaan belajar, dan latar belakang lingkungan siswa tersebut. Menurut Jufrida (2019: 32), keberhasilan siswa dalam belajar dipengaruhi oleh beberapa faktor yaitu 1) Faktor internal yang berasal dari diri sendiri seperti faktor fisiologis dan faktor psikologis meliputi minat, motivasi, bakat, konsentrasi, dan kebiasaan belajar. 2) Faktor eksternal yang berasal dari lingkungan sekitas siswa seperti faktor keluarga, sekolah, dan lingkungan masyarakat.

2. Peningkatan hasil belajar

Peningkatan hasil belajar siswa dilihat dari hasil pretest dan posttest, kemudian untuk mengetahui adanya peningkatan dianalisis menggunakan rumus N-Gain. Hasil analisis pretest, posttes, dan N-Gain terdapat pada Tabel 4.

Table 4. Peningkat Hasil Belajar

\begin{tabular}{ccccc}
\hline & \multicolumn{3}{c}{ Rata-rata } \\
\cline { 2 - 5 } Kelas & Pretest & Posttest & N-Gain & $\begin{array}{c}\text { Inter- } \\
\text { pretasi } \\
\text { N-Gain }\end{array}$ \\
\hline XI & 42,50 & 67,17 & 0,43 & Sedang \\
MIPA & & & & \\
5 & & & & \\
\hline
\end{tabular}

Tabel 4. menunjukan bahwa pengguanaan media pembelajaran Flipbook Interaktif dalam proses pembelajaran dapat meningkatkan hasil belajar siswa yang dibuktikan dengan adanya peningkatan hasil analisis pretest dan posttest, yaitu hasil rata-rata pretest sebesar 42,50 dan rata-rata posttest sebesar 67,17, serta rata-rata nilai $N$-Gain 0,43 dengan kategori sedang. Menurut Audie (2019: 588), menyatakan bahwa media pembelajaran yang menarik dan mudah digunakan merupakan salah satu faktor terjadinya peningkatan hasil belajar dan motivasi belajar siswa karena didalam media pembelajran ini terdapat pengetahuan yang dapat diingat oleh sisiwa. Peningkatan pengetahuan kognitif siswa ini dapat menjadi tolak ukur keberhasilan belajar siswa sehingga siswa dapat lebih bijak dalam menjalani kehidupannya. Menurut Audie (2019: 588), hasil belajar dapat meningkatkan perkembangan mental siswa menjadi lebih baik. Hasil belajar ini tidak hanya menigkatkan pengetahuan kognitif saja namun juga dapat meningkatkan afektif dan psikomotorik.

Ketercapaian tingkat kognitif siswa diukur dengan lembar pretest dan posttest dalam bentuk soal pilihan ganda. Tingkat kognitif yang digunakan pada penelitian ini mencakup C4, C5, dan C6. Persentase pencapaian tiap indikator kognitifnya terdapat pada Tabel 5.

Table 5. Persentase Pencapaian Tingkat Kognitif Siswa

\begin{tabular}{ccccc}
\hline Indi- & \multicolumn{2}{c}{ Pretest } & \multicolumn{2}{c}{ Posttest } \\
\cline { 2 - 5 } kator & $\begin{array}{c}\text { Rata- } \\
\text { rata }\end{array}$ & Kriteria & $\begin{array}{c}\text { Rata- } \\
\text { rata }\end{array}$ & Kriteria \\
\hline C4 & $51 \%$ & $\begin{array}{c}\text { Sangat } \\
\text { Kurang }\end{array}$ & $72 \%$ & Cukup \\
\hline
\end{tabular}




\begin{tabular}{ccccc}
\hline Indi- & \multicolumn{2}{c}{ Pretest } & \multicolumn{2}{c}{ Posttest } \\
\cline { 2 - 5 } kator & $\begin{array}{c}\text { Rata- } \\
\text { rata }\end{array}$ & Kriteria & $\begin{array}{c}\text { Rata- } \\
\text { rata }\end{array}$ & Kriteria \\
\hline C5 & $30,2 \%$ & $\begin{array}{c}\text { Sangat } \\
\text { Kurang }\end{array}$ & $51,3 \%$ & Kurang \\
C6 & $42 \%$ & $\begin{array}{r}\text { Sangat } \\
\text { Kurang }\end{array}$ & $70 \%$ & Cukup \\
\hline
\end{tabular}

Tabel 5. menunjukan bahwa berdasarkan hasil pretest kemampuan siswa pada indikator C4, C5, dan C6 masing-masing dengan kriteria sangat kurang. Berdasarkan hasil posttest terdapat kenaikan pencapaian tingkat kognitif siswa pada indikator C4 dan C6 menjadi kriteria cukup, sedangkan pada indikator C5 menjadi kriteria kurang.

Untuk mengetahui signifikansi media pembelajaran Flipbook Interaktif dalam membantu kenaikan hasil belajar siswa dilakukan dengan cara analisis hipotesis. Analisis awal yang dilakukan yaitu data hasil pretest dan posttes dilakukan dengan uji normalitas menggunakan rumus Lilefors. Hasil analisis uji normalitas terdapat pada Tabel 6 .

Table 6. Keterlaksanaan Aktivitas Guru

\begin{tabular}{ccccc}
\hline Kelas & Data & $\mathbf{L}^{2 \text { hitung }}$ & $\mathbf{L}^{2 \text { tabel }}$ & Kriteria \\
\hline XI & Pretest & 0,13 & 0,161 & Normal \\
MIPA 5 & Posttest & 0,08 & & \\
\hline
\end{tabular}

Tabel 6. menunjukan bahwa hasil uji normalitas pretest dan posttest kelas XI MIPA 5 berdistribusi normal, sehingga analisis data ini dapat dilanjutkan dengan melakukan uji homogenitas untuk mengetahui apakah kedua data tersebut bersifat homogen atau tidak yang terdapat pada Tabel 7 .
Table 7. Keterlaksanaan Aktivitas Guru

\begin{tabular}{ccccc}
\hline Kelas & Data & \multicolumn{2}{c}{ Uji F } & Kesim- \\
\cline { 3 - 4 } & & $\mathbf{F}_{\text {hitung }}$ & $\mathbf{F}_{\text {tabel }}$ & pulan \\
\hline XI & Pretest & 0,77 & 1,86 & Homogen \\
MIPA 5 & $\begin{array}{c}\text { dan } \\
\text { Posttest }\end{array}$ & & & \\
\hline
\end{tabular}

Tabel 7. menunjukan bahwa hasil uji homogenitas pretest dan posttest kelas XI MIPA 5 bersifat homogen dikarenakan Fhitung < Ftabel maka H0 diterima. Dikarenakan data berdistribusi normal dan bersifat homogenitas maka dilanjutkan dengan melakukan uji hipotesis menggunakan statistik parametrik dengan jenis uji $t$ berpasangan. Hasil uji hipotesis $t$ berpasangan terdapat pada Tabel 8 .

Table 8. Hasil Uji Hipotesis Pretest dan Posttest

\begin{tabular}{cccc}
\hline Kelas & Data & \multicolumn{2}{c}{ Uji t Berpasangan } \\
\cline { 3 - 4 } & & $\mathbf{t}_{\text {hitung }}$ & $\mathbf{t}_{\text {tabel }}$ \\
\hline XI MIPA & Pretest dan & $-8,9$ & $-1,67$ \\
5 & Posttest & & \\
\hline \multicolumn{3}{c}{ Tabel } & 8. menunjukan bahwa uji
\end{tabular}
hipotesis pretest dan posttest dengan taraf signifikansi $5 \%$ mendapatkan hasil $t_{\text {hitung }}(-8,9)<\mathrm{t}_{\text {tabel }}(-1,67)$, maka $\mathrm{H}_{0}$ ditolak dan $\mathrm{H}_{1}$ diterima. Berdasarkan hasil tersebut maka penggunaan media pembelajaran Flipbook Interaktif dapat membantu meningkatkan hasil belajar siswa secara signifikan pada materi struktur dan fungsi sel. Sejalan dengan penelitian Hamid (2021: 917), bahwa media pembelajaran Flipbook Interaktif layak digunakan untuk proses pembelajaran secara madiri, melalui media pembelajaran ini dapat meningkatkan minat siswa sehingga hasil belajar siswa menjadi meningkat. 
C. Respon Siswa Terhadap Penggunaan Media Pembelajaran Flipbook Interaktif pada Materi Struktur dan Fungsi Sel

Respon siswa terhadap pengguaan media pembelajaran Flipbook Interaktif diukur menggunakan angket. Angket ini terdiri dari 4 indikator yang kemudian dibuat pertanyaan sebanyak 10 item, Data yang diperoleh dari angket selanjutnya diolah dan dianalisis mengguakan skala likert. Rata-rata respon siswa terhadap media pembelajaran Flipbook Interaktif untuk setiap indikatornya terdapat pada Tabel 9.

Table 9. Rekapitulasi analisis respon siswa terhadap media pembelajaran Flipbook Interaktif

\begin{tabular}{cccc}
\hline Indikator & Jumlah & $\begin{array}{c}\text { Rata-rata } \\
\text { (\%) }\end{array}$ & $\begin{array}{c}\text { inter- } \\
\text { pretsi }\end{array}$ \\
\hline $\begin{array}{c}\text { Keefekti- } \\
\text { fan media }\end{array}$ & 375 & 83,3 & ST \\
$\begin{array}{c}\text { Flipbook } \\
\text { interaktif }\end{array}$ & & & \\
$\begin{array}{c}\text { Motivasi } \\
\text { belajar }\end{array}$ & 235 & 78,3 & $\mathrm{~T}$ \\
$\begin{array}{c}\text { Bahasa dan } \\
\text { penjelasan } \\
\text { materi }\end{array}$ & 370 & 82,2 & $\mathrm{ST}$ \\
$\begin{array}{c}\text { Keberhasi- } \\
\text { lan peng- } \\
\text { gunaan } \\
\text { media }\end{array}$ & 242 & 81 & $\mathrm{ST}$ \\
Flipbook & & & \\
\hline
\end{tabular}

Rata-rata 81 ST

Berdasarkan Tabel 9. menyatakan bahwa respon siswa tehadap media pembelajara Flipbook interaktif memperoleh rata-rata $81 \%$ dengan kategori ST (sangat tinggi). Pada setiap indikatornya pun siswa memberikan respon yang tinggi terhadap media pembelajara Flipbook interaktif. Berdasarkan perolehan rata-rata tersebut dapat disimpulkan bahwa siswa merasa mudah, menarik, dan termotivasi dalam belajar menggunakan media pembelajara Flipbook interaktif. Menurut Yayi (2019: 9), bahwa media pembelajaran dengan berbentuk buku digital yang interaktif dengan tampilan yang menarik dan penggunaan yang mudah dapat menjadi pendukung pembelajaran secara online.

Media pembelajaran Flipbook Interaktif juga dapat meningkatkan motivasi belajar siswa secara mandiri karena dengan pembelajaran secara online butuh suatu pengemasan materi secara menarik agar meningkatnya motivasi belajar siswa. Tampilan media pembelajaran Flipbook Interaktif ini dengan menggabungkan beberapa media seperti struktur kalimat yang mudah dipahami, video, dan animasi yang menarik dan jelas akan memudahkan siswa dalam memahami materi. Menurut Fahmi (2018: 703), bahwa media pembelajaran yang dilengkapi dengan teks yang berwarna, video, animasi, dan audio dapat terjadinya pembelajaran yang interaktif karena melibatkan gaya belajar secara aduatif, visual, dan kinetik, sehingga dari perbedaan gaya belajar setiap siswa dapat memudahkan untuk menerima materi. Media pembelajaran Flipbook Interaktif dinilai dapat memepermudahkan siswa dalam mengerjakan soal evaluasi hal ini dibuktikan adanya peningkatan hasil posttes setelah mendapatkan materi melalui media pembelajaran Flipbook Interaktif. Menurut Setiawan (2020: 109), media pembelajaran Flipbook 
Interaktif dapat meningkatkan hasil pemahaman materi dan kualitas pembelajaran yang lebih baik secara interaktif dan tampilan media yang menarik dapat meningkatkan motivasi siswa untuk belajar, selain itu juga dengan menggunakan media ini dapat menciptakan pembelajaran yang efektif dan efesiens, serta proses pembelajaran dapat dilakukan secara mandiri dimana saja. media pembelajaran Flipbook Interaktif ini dapat mengemas gambar, audio, dan video sehingga dapat membantu siswa untuk memahami materi.

\section{SIMPULAN}

Berdasarkan hasil penelitian tersebut maka diperoleh kesimpulan sebagai berikut:

1. Pembelajaran dengan menggunakan media pembelajaran Flipbook Interaktif pada materi Struktur dan Fungsi Sel terlaksana dengan baik, dengan ratarata persentase keterlaksanaan aktivitas guru sebesar $94 \%$ dan hasil rata-rata persentase keterlaksanaan aktivitas siswa sebesar $74,16 \%$.

2. Penerapan media pembelajatan Flipbook Interaktif pada materi Struktur dan Fungsi Sel, dapat membantu meningkatkan hasil belajar siswa sebesar N-Gain 0,43 dengan kategori sedang.

3. Respon siswa terhadap pembelajaran dengan media pembelajaran Flipbbook Interaktif pada materi Struktur dan Fungsi Sel adalah $81 \%$ dengan kategori tinggi.

\section{DAFTAR PUSTAKA}

Audie, Nurul. (2019). Peran Media Pembelajaran Meningkatkan Hasil Belajar Peserta Didik. Posiding Seminar Nasional Pendidikan FKIP. 2(1): 586-595.

Fadilah A.A., dan Fakhruddin F. (2019). Jurnal of Nonformal Education and Community Empowermwnt. Manajemen Pembelajaran Pelatihan Persiapan Program Magang. 3(2): 149159.

Fahmi Syariful., dan Priwantoro S.W. (2018). Analisis Kebutuhan Pengembangan Media Pembelajaran Interaktif Menggunakan Kvisoft Flipbook Maker Untuk Mata Kuliah Multimedia Pembelajaran Matematika. Seminar Nasional Pendidikan Matematika Ahmad Dahlan 2018. hal 700-703.

Halik A.l., dan Zamratul A.I. (2020). Analisis Keaktifan Siswa dalam Proses Pembelajaran Daring di Masa Pandemi COVID-19. Jurnal Bimbingan Konseling Islam. 3(2):131-141.

Hamid, Aisyah, dan Alberida, Heffi. (2021). Pentingnya MengembangkanEModul Interaktif Berbasis Flipbook di Sekolah Menengah Atas. Jurnal Ilmu Pendidikan. 3(3): 911-918.

Istani L.G.M.Z. (2020). Transformasi Media Pembelajaran Pada Masa Pandemi Covid-19. Jurnal Studi Islam, $1(1), 82-93$.

Jufrida, Basuki F.R., Pangestu M.D., \& Prasetya N.AD. (2019). Analisis Faktor yang Mempengaruhi Hasil Belajar IPA dan Literasi Sains di SMP Negeri 1 Muaro Jambi. Jurnal Pendidikan Fisika. 4(2): 31-38.

Kurniawan B., Wiharna O., \& Permana T. (2017). Studi Analisis Faktor-Faktor yang Mempengaruhi Hasil Belajar Pada Mata Pelajaran Teknik Listrik Dasar Otomotif. Journal of Mechanical Engineering Education. 4(2), 156-162.

Mulyadi D.U., Wahyuni S., \& Handayani R.D. (2016). Pengembangan Media Flash Flipbook Untuk Meningkatkan Berfikir Kreatif Siswa Dalam Pembelajaran IPA di SMP. Jurnal Pembelajaran Fisika, 4(4), 296-301. 
Indonesian Journal of Mathematics and Natural Science Education, 2 (2), 2021

Diana Rahayu, R. Ading Pramadi, Meti Maspupah, Tri Wabyuni Agustina

Nurrita, Teni. (2018) Pengembangan Media Pembelajaran untuk Meningkatkan Hasil Belajar Siswa. Misykat: Jurnal Ilmu-ilmu Al-Qur'an, Hadist, Syari'ah dan Tarbiyah. 3 (1) 2018 hal: 171-187

Purnamasari I., Fadillah, \& Warneri. (2019). Pengembangan Multimedia Pembelajaran Biologi Materi Struktur dan Fungsi Sel di SMAN 1 Teluk Keramat. Jurnal Pendidikan dan Pembelajaran Khatulistiwa.. 8(11): 1-11.

Yayi F.P., \& Yuliana. A. (2019). Pengembangan
Pembelajaran dalam Bentuk Buku Digital Interaktif Berbasis Flipbook Bagi mahasiswa Teknik Mesin. Jurnal pendidikan Teknik Eletro. 4(2). 1-10.

\section{PROFIL SINGKAT}

Diana Rahayu, lahir di Karawang 03 Maret 1999, pendidikan terakhir S1 Pendidikan Biologi UIN Sunan Gunung Djati Bandung, lulus kuliah pada tahun 2021. 